Bird Conservation International (2022) 32:188-205. (C) The Author(s), 2021. Published by Cambridge University Press on behalf of BirdLife International. This is an Open Access article, distributed under the terms of the Creative Commons Attribution licence (https://creativecommons.org/licenses/by/4.o/), which permits unrestricted re-use, distribution, and reproduction in any medium, provided the original work is properly cited.

doi:10.1017/S0959270921000228

\title{
Priority areas for vulture conservation in the Horn of Africa largely fall outside the protected area network
}

\author{
EVAN R. BUECHLEY ${ }^{1,2,3 *}$ (D), MARCO GIRARDELLO ${ }^{4}$, ANDREA SANTANGELI $^{5,6}$, \\ ALAZAR DAKA RUFFO ${ }^{7}$, GIRMA AYALEW $^{8}$, YILMA D. ABEBE$^{9}$, \\ DAVID R. BARBER ${ }^{10}$, RALPH BUIJ $^{11,12}$, KEITH BILDSTEIN $^{13}$, \\ BRUKTAWIT ABDU MAHAMUED ${ }^{14}$, MONTAGUE H.C. NEATE-CLEGG ${ }^{2}$, \\ DARCY OGADA ${ }^{11,15}$, PETER P. MARRA ${ }^{16}$ (D), T. SCOTT SILLETT ${ }^{2}$, \\ JEAN-MARC THIOLLAY ${ }^{17}$, MARTIN WIKELSKI ${ }^{18,19}$, PETER YAWORSKY ${ }^{20,21}$ and \\ ÇAĞAN H. ŞEKERCIOĞLU ${ }^{2,22,23}$
}

${ }^{1}$ HawkWatch International, 2240 South 900 East, Salt Lake City, UT 84106, USA.

${ }^{2}$ School of Biological Sciences, The University of Utah, 257 South 1400 East, Salt Lake City, UT 84112, USA.

${ }^{3}$ Migratory Bird Center, Smithsonian Conservation Biology Institute, National Zoological Park, MRC 5503, Washington, DC 20013-7012, USA.

${ }^{4} \mathrm{cE} 3 \mathrm{c}$-Centre for Ecology, Evolution and Environmental Changes / Azorean Biodiversity Group and Universidade dos Açores - Faculty of Agriculture and Environment, Rua Capitão João d'Ávila, São Pedro, PT-970o-o42 Angra do Heroísmo, Terceira, Açores, Portugal.

${ }^{5}$ The Helsinki Lab of Ornithology, Finnish Museum of Natural History, FI-ooo14, University of Helsinki, Finland.

${ }^{6}$ FitzPatrick Institute of African Ornithology, DST-NRF Centre of Excellence, University of Cape Town, Cape Town, South Africa.

${ }^{7}$ Addis Ababa University, Faculty of Natural Science, Department of Zoological Sciences, Ethiopia.

${ }^{8}$ Ethiopian Wildlife Conservation Authority, Addis Ababa, Ethiopia.

${ }^{9}$ P.O. Box 18112, Addis Ababa, Ethiopia.

${ }^{10}$ Acopian Center for Conservation Learning, Hawk Mountain Sanctuary, 410 Summer Valley Road, Orwigsburg, PA 17961, USA.

${ }^{11}$ The Peregrine Fund, 5668 West Flying Hawk Lane Boise, ID 83709, USA.

${ }^{12}$ Wageningen University \& Research, Droevendaalsesteeg $3 A, 6708$ PB Wageningen, The Netherlands.

${ }^{13} 116$ Village Drive, Blandon, PA, 19510, USA.

${ }^{14}$ Kotebe Metropolitan University, Addis Ababa, Ethiopia.

${ }^{15}$ National Museums of Kenya, Ornithology Section, P.O. Box 40658- 0010o, Nairobi, Kenya.

${ }^{16}$ Department of Biology and McCourt School of Public Policy, Georgetown University, 37th and O Streets NW, Washington, DC 20057, USA.

${ }^{17} 2$ rue de la Rivière, 10220 Rouilly Sacey, France.

${ }^{18}$ Department of Migration, Max Planck Institute of Animal Behavior, 78315 Radolfzell, Germany.

${ }^{19}$ Centre for the Advanced Study of Collective Behaviour, University of Konstanz, 78457 Konstanz, Germany.

${ }^{20}$ Department of Anthropology, University of Utah, 260 Central Campus Drive, Salt Lake City, Utah, 84112, USA.

${ }^{21}$ Archaeological Center, University of Utah, 260 Central Campus Drive, Salt Lake City, Utah, 84112, USA.

${ }^{22}$ Department of Molecular Biology and Genetics, Koç University, Istanbul, Turkey. 
${ }^{23}$ KuzeyDoğa Derne ği, Ortakapı Mah. Şehit Yusuf Bey Cad. No:69 Kat:1 36100 Merkez, Kars,
Turkey.

*Author for correspondence; email: ebuechley@gmail.com

(Received 10 February 2021; revision accepted 05 May 2021)

\section{Summary}

Vulture populations are in severe decline across Africa and prioritization of geographic areas for their conservation is urgently needed. To do so, we compiled three independent datasets on vulture occurrence from road-surveys, GPS-tracking, and citizen science (eBird), and used maximum entropy to build ensemble species distribution models (SDMs). We then identified spatial vulture conservation priorities in Ethiopia, a stronghold for vultures in Africa, while accounting for uncertainty in our predictions. We were able to build robust distribution models for five vulture species across the entirety of Ethiopia, including three Critically Endangered, one Endangered, and one Near Threatened species. We show that priorities occur in the highlands of Ethiopia, which provide particularly important habitat for Bearded Gypaetus barbatus, Hooded Necrosyrtes monachus, Rüppell's Gyps rüppelli and White-backed Gyps africanus Vultures, as well as the lowlands of north-eastern Ethiopia, which are particularly valuable for the Egyptian Vulture Neophron percnopterus. One-third of the core distribution of the Egyptian Vulture was protected, followed by the White-backed Vulture at one-sixth, and all other species at one-tenth. Overall, only about onefifth of vulture priority areas were protected. Given that there is limited protection of priority areas and that vultures range widely, we argue that measures of broad spatial and legislative scope will be necessary to address drivers of vulture declines, including poisoning, energy infrastructure, and climate change, while considering the local social context and aiding sustainable development.

Keywords: conservation prioritization, Ethiopia, vulture safe zones, ecological niche modeling, species distribution model (SDM)

\section{Introduction}

Current species extinction rates are an estimated 1,000 times over the background rate and are expected to increase with growing anthropogenic pressures worldwide (Barnosky et al. 2011). Loss of species and wildlife abundance is compromising ecological processes, reducing ecosystem services, and directly affecting humans (Şekercioğlu 2010, Cadotte et al. 2011). Tropical biodiversity is generally less studied than temperate biodiversity (Trimble and van Aarde 2012) and the tropics are expected to experience the greatest biodiversity losses in the $21^{\text {st }}$ century (Alroy 2017). Overcoming this trend will require international investment and local community support (Ghosh-Harihar et al. 2019). As biodiversity and threats are unevenly distributed, limited research and conservation investments should be strategically targeted to maximize effectiveness (Brooks et al. 2006) and to fill threat gaps (Joppa et al. 2016).

As scavengers, vultures constitute the most endangered functional guild of birds and their populations are in severe decline worldwide (Buechley and Şekercioğlu 2016a,b). They are a top conservation priority because they are highly threatened and provide critical ecological functions by quickly consuming carrion, contributing to nutrient cycling and regulation of problematic facultative scavengers (Ogada et al. 2012) and, potentially, controlling disease (Buechley and 
Şekercioğlu 2016a, Devault et al. 2016, Plaza et al. 2020). Vultures face a range of threats, including most notably, poisoning, toxic veterinary drugs, loss of food availability, and collision and electrocution on energy infrastructure (Buechley and Şekercioğlu 2016a, Botha et al. 2017, Plaza et al. 2019). Given their broad distributions, large individual home ranges, and long-distance nomadic and migratory movements, conservation of vultures is challenging (e.g. Runge et al. 2014, 2015). Prioritizing geographic areas for conservation actions is needed (Mukherjee et al. 2014, Santangeli et al. 2019a). Indeed, the recently published Multi-Species Action Plan to Conserve AfricanEurasian Vultures (Vulture MSAP), which is based on extensive expert input, provides a roadmap for vulture conservation across Africa and Eurasia, highlighting the need to identify threats and prioritize conservation actions at different spatial scales (Botha et al. 2017).

To identify spatial conservation priorities, it is essential to know the distribution and habitat use of species. Species distribution models (SDMs) are an important tool used to identify priority habitats and to forecast anthropogenic effects on species (Guisan and Thuiller 2005, Aryal et al. 2016). Combined with information on protected areas and existing threats to species, SDMs can help identify conservation priorities (Ferraz et al. 2012, Evans et al. 2018). However, the accuracy of SDMs is limited by the availability of both occurrence (i.e. where a species occurs) and predictor variables (i.e. spatial layers relevant to model a species' distribution) (Fletcher Jr et al. 2018), both of which can be limited in the Global South. Targeted survey data are costly and time consuming, and thus generally scarce. Bio-logging (e.g. GPS tracking) can be used to model species' distributions (e.g. Coxen et al. 2017), but can suffer from small sample sizes. Citizen science data (e.g. eBird; Sullivan et al. 2014) are being increasingly used to fill information gaps and have been shown to be useful for modelling bird distributions and population trends (Horns et al. 2018, Fink et al. 2019), but have spatial and observer biases (Fletcher Jr et al. 2018, Horns et al. 2018, Fink et al. 2019, Neate-Clegg et al. 2020). Combining multiple data sources to model species' distributions can help increase predictive accuracy and account for sampling biases (Fletcher Jr et al. 2018, Miller et al. 2019).

Here we used an SDM framework to identify spatial conservation priorities for vultures in Ethiopia, a high-priority country for vulture conservation (Santangeli et al. 2019a). Our aims were to: 1) model the distribution of each vulture species; 2) identify vulture conservation priority areas; and 3) assess how well protected vulture priority areas are. We incorporated three independent datasets on vulture occurrence (road-surveys, GPS-tracking, and citizen science) to build robust predictions on vulture space use. Our results provide a framework for where to prioritize conservation work on endangered vultures in the Horn of Africa.

\section{Methods}

\section{Study location and species}

The study took place in Ethiopia, a biologically diverse and little-studied country, which supports one of the most species rich and abundant vulture communities worldwide (Mundy et al. 1993, Buechley et al. 2019). It is also the second most populous country in Africa and has a high human population growth rate (2.46\% per year) (World Bank 2019b). Despite being one of the poorest countries in the world, Ethiopia is developing rapidly (World Bank 2019a), and there is severe pressure on natural ecosystems. Seven vulture species reside in Ethiopia: Bearded Gypaetus barbatus ('Near Threatened'), Egyptian Neophron percnopterus ('Endangered'), Hooded Necrosyrtes monachus ('Critically Endangered'), Lappet-faced Torgos tracheliotos ('Endangered'), Rüppell's Gyps rueppelli ('Critically Endangered'), Whitebacked Gyps africanus ('Critically Endangered'), and White-headed Trigonoceps occipitalis ('Critically Endangered') (Botha et al. 2017). The largest African populations of Bearded and Egyptian Vultures are thought to occur in Ethiopia (Arkumarev et al. 2014, Botha et al. 2017). 


\section{Species occurrence data}

Vulture occurrence data were acquired from three independent sources: road-surveys, satellite telemetry, and citizen science. Road-surveys took place in Ethiopia from 2010 to 2018, whereby two experienced raptor biologists completed $10,857 \mathrm{~km}$ of surveys, while driving at speeds $<60 \mathrm{~km}$ per hour during daylight hours, identifying perched and flying vultures within $\mathrm{I} \mathrm{km}$ of the road. Citizen science observations of vultures were downloaded via the comprehensive eBird Basic Dataset (Sullivan et al. 2014) for Ethiopia, and censored to minimise sampling and observer bias, following specific recommendations and code provided by Johnston et al. (2019). Satellite tracking data were collected by deploying 34 solar-powered GPS-transmitters on vultures in or ranging through Ethiopia from 2012 to 2018, including 15 Egyptian, eight White-backed, six Hooded, three Ruppell's, and two Lappet-faced vultures. See Figure $S_{I}$ in the online supplementary material for an overview of occurrence data. Further details on acquisition and treatment of occurrence data are in Appendix Si.

Each dataset had strengths and weaknesses. For example, road-surveys were designed to have broad geographic coverage and high data quality, but were limited by the extent of the road network and security concerns inhibiting access to some areas. Further, road-surveys took place only during the dry season, and seasonal differences in vulture ranging behaviour has been shown elsewhere in Africa (e.g. Kendall et al. 2014), indicating that these surveys may not have captured each species' full environmental niche. In contrast, satellite-tracking provided a picture of the habitat use of individual vultures throughout the full annual cycle, but had a limited sample of individuals. Meanwhile, citizen science data had broad geographic and temporal coverage, but were spatially biased towards urban centres and birding "hotspots", and may have suffered from lower data quality due to potential species misidentification (e.g. Fink et al. 2019). We recognize that each of the data types was therefore capturing different aspects of the species' ecological niche and at somewhat different spatial and temporal scales, and we see that as a net benefit of our approach. By incorporating multiple data types, we maximized the number of species for which we had sufficient data to model distributions, while also incorporating data that captured different aspects of each species' environmental niche.

All analyses were completed in R (Version 3.1.0; R Core Team 2019). For eBird data, occurrence points were observations for each species spatially rarefied to a $1-\mathrm{km}$ distance, while the background sample was the location of all complete checklists (Coxen et al. 2017). For road-survey data, we buffered road transects by $1 \mathrm{~km}$ on both sides of the road, overlaid a $1-\mathrm{km}^{2}$ raster grid over the survey area, and aggregated observations for each species within each pixel, such that any pixel where a given vulture species was sighted was given a value of $I$ (occurrence), whereas pixels where that vulture species was not encountered were given a value of o (background). For satellite tracking data, we calculated the $95 \%$ minimum convex polygon (MCP) cumulative home range ('adehabitatHR' package; Clemente Calenge 201I) of all tracked individuals of each species (with one exception: we calculated separate MCPs for two Hooded Vulture populations that did not overlap from transmitter deployments in northern and southern Ethiopia). Tracked vulture locations within each species' MCP were used as occurrence points, while background points were drawn from a systematic sample of 10,000 evenly spaced points within the MCP for each species (Benson 2013).

\section{Environmental variables}

We compiled environmental data that were expected to influence vulture use, including habitat type (European Space Agency 2017), elevation and ruggedness (Robinson et al. 2014), human footprint (Venter et al. 2016), climate (annually averaged temperature, precipitation, wind, solar radiation; Fick and Hijmans 2017), latitude and longitude. Prior to modelling, we assessed correlation of predictor variables by creating a correlation matrix using 'corrplot' (Wei and Simko 2013), and reviewed the variance inflation factors using the 'usdm' package (Naimi 2015). We used a 
cutoff of $|r|=0.60$ as an indication of strong co-linearity (Crandall et al. 2015). Elevation and temperature were inversely correlated $(|r|=-I)$ and we thus excluded elevation because temperature was expected to have a more direct biological effect. Wind, precipitation, and longitude were highly correlated with other variables and were removed, leaving us with 12 predictor variables: latitude, ruggedness, human footprint, distance to cropland, distance to desert, distance to forest, distance to grassland, distance to shrubland, distance to urban, categorical landcover class, temperature, and solar radiation (Figure $\mathrm{S}_{3}$ ). Further details on processing of predictor variables can be found in Appendix $\mathrm{S}_{1}$.

\section{Species distribution models}

We modelled the distributions of seven vulture species in Ethiopia using maximum entropy (Maxent; Phillips et al. 2006). Maxent is the most widely used species distribution modeling technique (Elith et al. 201I). To maximize the accuracy of Maxent models, it is important to account for sampling bias of occurrence points, to select the appropriate background sample, and to select the best regularization multiplier (Merow et al. 2013). To address these concerns, we spatially thinned each dataset, carefully selected the background sample, and tested a range of regularization multipliers. Maxent was run using the package 'ENMeval' (Muscarella et al. 2014), using "algorithm = 'maxent.jar'", which interfaces with the standalone Maxent program (Version 3.4.1; Phillips and Dudík 2020). For each data type and species combination, we ran a suite of models with a range of regularization multiplier values (from $I$ to 4 , by 1 ) and feature class combinations (L, LQ, H, LQH, LQHP, LQHPT; where $\mathrm{L}=$ linear, $\mathrm{Q}=$ quadratic, $\mathrm{H}=$ hinge, $\mathrm{P}=$ product and $\mathrm{T}=$ threshold), or up to 24 models each. To assess the predictive capacity of each model, we used $k$-fold internal cross validation (Merow et al. 2013) with four folds (we used $75 \%$ of the data to train the model and $25 \%$ of the data to test the model), using the 'block' data partitioning method, which spatially partitions data into four bins by the lines of latitude and longitude that divide occurrence localities as equally as possible. We selected the top model for each species and data type using Akaike information criteria corrected for small sample sizes (AICc) (Burnham and Anderson 2004, Muscarella et al. 2014). Predictive accuracy of top models was assessed from the $\mathrm{AUC}_{\text {test }}$ score, which measures the model's ability to discriminate between conditions at occurrence versus background locations (Muscarella et al. 2014). We also report $\mathrm{OR}_{\mathrm{MTP}}$, which is the average omission rate of the occurrence records at the minimum training presence (MTP) threshold, where MTP represents an estimate of species habitat suitability (Muscarella et al. 2014, Taylor et al. 2020). We deemed models with $\mathrm{AUC}_{\text {test }}$ values $>0.60$ to be informative (Randin et al. 2006).

Next, we compared the top predictions for each species and data type, using Hellinger's I statistic. Hellinger's I values range from o (no overlap) to I (complete overlap), quantifying niche overlap over geographic space while making no assumptions about species density (Warren et al. 2008).

Then for each species we created an ensemble species distribution model. To do so, we weighted the top species-data type model by its respective AUC test score and then summed them. We mapped the final predicted ensemble distribution of each species across Ethiopia, interpreted as relative habitat suitability (Merow et al. 2013).

To estimate uncertainty in our predictions, we took 10 bootstrap samples of the training datasets and ran predictions for each species and data type combination on each bootstrapped sample. We then calculated the standard deviation of the predicted values for each species and data type combination and derived an overall map of the uncertainty in the modelled distribution for each species by taking the average of the standard deviation values across each data type.

We identified the core distribution of each species within Ethiopia as the top $30 \%$ of its predicted distribution areas. While the $30 \%$ threshold is somewhat arbitrary, it follows other recent work prioritizing conservation areas for vultures across the Old World (Santangeli et al. 2019a). We then calculated overlap of the core distribution with protected areas (PAs; considering IUCN protected area categories I to VI; IUCN and UNE P-WCMC 2018) and Important Bird and Biodiversity Areas (IBAs; BirdLife International 2020). 


\section{Identifying priority conservation areas}

We combined the final ensemble species distributions for each vulture species to identify priority conservation areas for all vultures in Ethiopia using software Zonation Version 4.o (Moilanen et al. 2014). Zonation ranks areas of conservation importance by iteratively removing grid cells starting from those that have the lowest value for conservation. We used the core area cell removal method (CAZ), such that high priority areas include important habitat for each species, i.e. a 'leave no species behind' approach, at a 1-km² pixel resolution (Santangeli et al. 2019a). In order to assess the robustness of the main priority map, we incorporated the prediction uncertainty layers we created (see above) directly into the prioritization analysis using the distribution discounting tool in Zonation (Moilanen et al., 2006), such that the highest-ranking sites have high conservation value and low uncertainty. We ran the zonation analyses three times, setting the uncertainty parameter to subtract $0,0.5$, and I SD, from the nominal estimates of the input layers of analysis. We report on the intermediary output ( $0.5 \mathrm{SD}$ ) in the main text and provide the other outputs in Figure $\mathrm{S}_{5}$. Through the prioritization, all species were given the same weight. An alternative approach could be to weight species according to their global conservation status (e.g. Santangeli et al. 2019). However, we decided to give species equal weight, provided that our exercise was national, and considering that Ethiopia may provide particularly important habitat for some of the less threatened species, particularly Bearded and Egyptian Vultures (Botha et al. 2017). Next, we identified "vulture priority areas" in Ethiopia as the top $30 \%$ of the zonation output and calculated the area of overlap and the average priority of each PA and IBA in the country for vulture conservation.

\section{Results}

\section{Species distribution models}

We produced an ensemble SDM for five of the seven vulture species considered. Ensemble models were based on three data types for Egyptian and Hooded, two data types for Bearded and Rüppell's, and one data type for White-backed Vulture (Table I). AUC $C_{\text {test }}$ values for models used ranged from 0.606 for the Rüppell's Vulture road-survey model to 0.928 for the Egyptian Vulture road-survey model (Table I). Predicted distributions for each species from different data types showed a high level of niche overlap (Hellinger's I statistic values ranged from 0.759 to 0.973 ; Table S1), indicating that the different datasets had largely similar predictions of each species' distribution.

The leading predictor of Bearded Vulture occurrence was lower temperature, which was equivalent to higher elevations in Ethiopia, as well as more rugged areas. In contrast, Egyptian Vulture occurrence was best predicted by hotter temperatures, i.e. lowland desert areas. Hooded Vulture favoured human-dominated landscapes, while avoiding shrubland. Rüppell's Vulture distribution was primarily predicted by ruggedness, as well as cooler, higher elevations. Whitebacked Vulture favoured cropland and forest habitats, proximity to urban centres, and cooler/ higher elevations.

The core range of the Egyptian Vulture was best protected (PA coverage $=32.8 \%$, IBA coverage $=7.8 \%)$, followed by White-backed $(\mathrm{PA}=14.3 \%$, IBA $=5.2 \%)$, Rüppell's $(\mathrm{PA}=11.9 \%$, IBA = $9.6 \%)$, Bearded $(\mathrm{PA}=10.5 \%, \mathrm{IBA}=13.1 \%)$, and Hooded $(\mathrm{PA}=9.3 \%, \mathrm{IBA}=7.1 \%)$ Vultures (Table S2). The final ensemble species distribution models for each species are shown in Figure $I$ and the average variable importance in the final ensemble model for each species is shown in Figure 2.

\section{Priority conservation areas}

Vulture conservation priority areas occurred throughout the highlands of Ethiopia, as well as the lowlands in the north-east of the country (Figure 3a). Southern and eastern Ethiopia had generally 
Table 1. Features and evaluation metrics of Maxent distribution models for seven vulture species in Ethiopia based on up to three data types. AUC test measures the model's ability to discriminate between conditions at test versus background locations, while $\mathrm{OR}_{\mathrm{MTP}}$ measures model overfitting (see text for details). For eBird and road-survey models, $n$ refers to the number of observations, whereas for telemetry models $n$ refers to the number of tracked individuals. Models with $\mathrm{AUC}_{\text {test }}<0.6$, shaded in grey, were deemed uninformative and excluded from further analyses. Models were not run for species lacking a sufficient sample size $(<20$ records for eBird or road-surveys, or $<5$ individuals for telemetry) and thus their values are NAs, but are included here to show sample size $(n)$.

\begin{tabular}{|c|c|c|c|c|c|c|c|c|}
\hline Species & Model & $n$ & Features & $\mathrm{rm}$ & Parameters & $\begin{array}{c}\text { AUC. } \\
\text { test }\end{array}$ & $\begin{array}{l}\text { OR. } \\
\text { mtp }\end{array}$ & $\begin{array}{l}\text { Model } \\
\text { weight } \\
\end{array}$ \\
\hline Bearded Vulture & $\begin{array}{l}\text { citizen } \\
\text { science }\end{array}$ & 60 & $\mathrm{~L}$ & 3 & 9 & 0.913 & 0.050 & 0.782 \\
\hline Bearded Vulture & $\begin{array}{l}\text { expert } \\
\text { survey }\end{array}$ & 29 & $\mathrm{~L}$ & 4 & 9 & 0.860 & 0.071 & 0.651 \\
\hline Egyptian Vulture & $\begin{array}{l}\text { citizen } \\
\text { science }\end{array}$ & 39 & LQHP & 4 & 15 & 0.730 & 0.125 & 0.324 \\
\hline Egyptian Vulture & $\begin{array}{l}\text { expert } \\
\text { survey }\end{array}$ & 46 & LQH & 4 & 15 & 0.928 & 0.000 & 0.819 \\
\hline Egyptian Vulture & telemetry & 15 & LQHP & 4 & 105 & 0.852 & 0.004 & 0.629 \\
\hline Hooded Vulture & $\begin{array}{l}\text { citizen } \\
\text { science }\end{array}$ & 513 & LQ & 1 & 24 & 0.691 & 0.002 & 0.227 \\
\hline Hooded Vulture & $\begin{array}{l}\text { expert } \\
\text { survey }\end{array}$ & 473 & LQ & 1 & 31 & 0.735 & 0.013 & 0.338 \\
\hline Hooded Vulture & telemetry & 6 & LQH & 4 & 47 & 0.779 & 0.075 & 0.448 \\
\hline $\begin{array}{l}\text { Lappet-faced } \\
\text { Vulture }\end{array}$ & $\begin{array}{l}\text { citizen } \\
\text { science }\end{array}$ & 25 & $\mathrm{~L}$ & 4 & 1 & 0.489 & 0.042 & o \\
\hline $\begin{array}{l}\text { Lappet-faced } \\
\text { Vulture }\end{array}$ & $\begin{array}{l}\text { expert } \\
\text { survey }\end{array}$ & 13 & NA & NA & NA & NA & NA & NA \\
\hline $\begin{array}{l}\text { Lappet-faced } \\
\text { Vulture }\end{array}$ & telemetry & 2 & NA & NA & NA & NA & NA & NA \\
\hline Ruppell's Vulture & $\begin{array}{l}\text { citizen } \\
\text { science }\end{array}$ & 128 & LQH & 2 & 15 & 0.733 & 0.055 & 0.332 \\
\hline Ruppell's Vulture & $\begin{array}{l}\text { expert } \\
\text { survey }\end{array}$ & 118 & $\mathrm{~L}$ & 2 & 11 & 0.606 & 0.042 & 0.015 \\
\hline Ruppell's Vulture & telemetry & 3 & NA & NA & NA & NA & NA & NA \\
\hline $\begin{array}{l}\text { White-backed } \\
\text { Vulture }\end{array}$ & $\begin{array}{l}\text { citizen } \\
\text { science }\end{array}$ & 164 & LQ & 1 & 19 & 0.563 & 0.037 & o \\
\hline $\begin{array}{l}\text { White-backed } \\
\text { Vulture }\end{array}$ & $\begin{array}{l}\text { expert } \\
\text { survey }\end{array}$ & 182 & LQ & 1 & 20 & 0.664 & 0.022 & 0.160 \\
\hline $\begin{array}{l}\text { White-backed } \\
\text { Vulture }\end{array}$ & telemetry & 8 & LQH & 4 & 66 & 0.576 & 0.165 & o \\
\hline $\begin{array}{l}\text { White-headed } \\
\text { Vulture }\end{array}$ & $\begin{array}{l}\text { citizen } \\
\text { science }\end{array}$ & 17 & NA & NA & NA & NA & NA & NA \\
\hline $\begin{array}{l}\text { White-headed } \\
\text { Vulture }\end{array}$ & $\begin{array}{l}\text { expert } \\
\text { survey }\end{array}$ & 3 & NA & NA & NA & NA & NA & NA \\
\hline
\end{tabular}

lower priority. The highest priority protected areas included Simien Mountains and Yangudi-Rassa National Parks, as well as several national forests (Figure $3 b$ ). These results were robust to uncertainty in predicted vulture distributions (Figure $\mathrm{S}_{5}$ ). Most of the highest priority IBAs were located in the vicinity of the capital city Addis Ababa in central Ethiopia (Figure $3 \mathrm{c}$ ). The top $30 \%$ vulture priority areas encompassed an area of $338,388 \mathrm{~km}^{2}$, of which $19.4 \%$ was covered by protected areas and $8.6 \%$ was covered by IBAs. See Appendices $S_{2}$ and $S_{3}$ for a full list of protected areas and IBAs with their priority rank. 

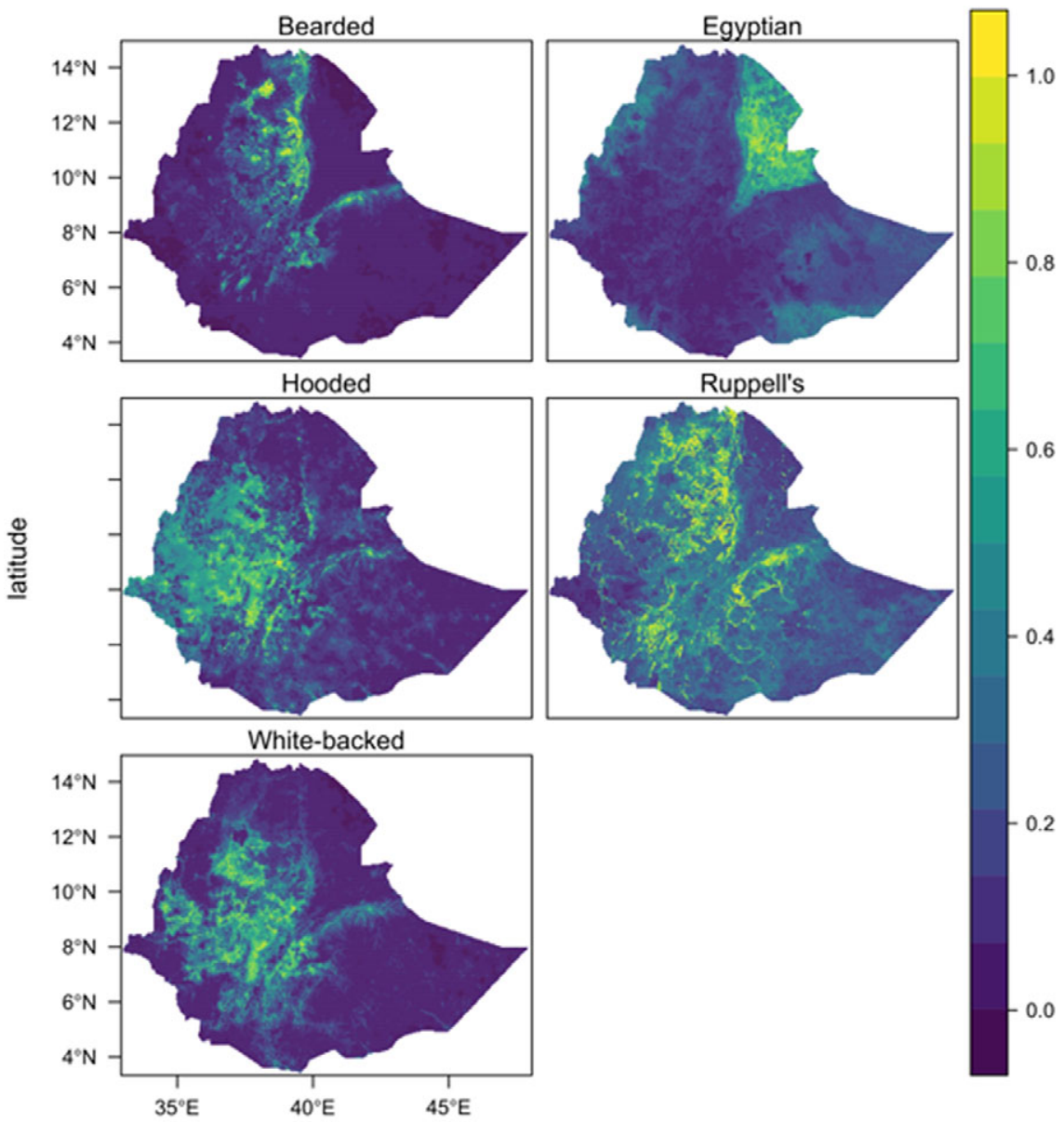

\section{longitude}

Figure 1. Ensemble species distribution models for five vulture species in Ethiopia based on up to three data sources per species (eBird, road-survey, satellite telemetry), weighted by their respective predictive accuracy, and summed. The predicted value, i.e. relative habitat suitability, ranges from $\mathrm{O}$ to $I$ and is a measure of the relative probability that a species occurs on the landscape.

\section{Discussion}

We provide the first quantitative analysis of vulture distributions in Ethiopia to identify spatial conservation priorities. We created ensemble models with up to three data sources per species to incorporate as much information as possible regarding each species' ecological niche. Priority areas occurred broadly in the central highlands of Ethiopia, which provide particularly important habitat for Bearded, Hooded, Rüppell's and White-backed Vultures, as well as the lowlands of northeastern Ethiopia, which are particularly valuable for the Egyptian Vulture (Figure 1, Figure 3). One-fifth of vulture priority areas were covered by protected areas, while less than one-tenth were covered by IBAs. Species core ranges were variably protected, with the Egyptian Vulture faring best at one-third protected, followed by White-backed Vulture at one-sixth, and all other species at onetenth. That the vast majority (i.e. approximately $80 \%$ ) of priority areas for vultures in Ethiopia fall outside the protected area network is in contrast to other studies in Africa that have shown vultures 


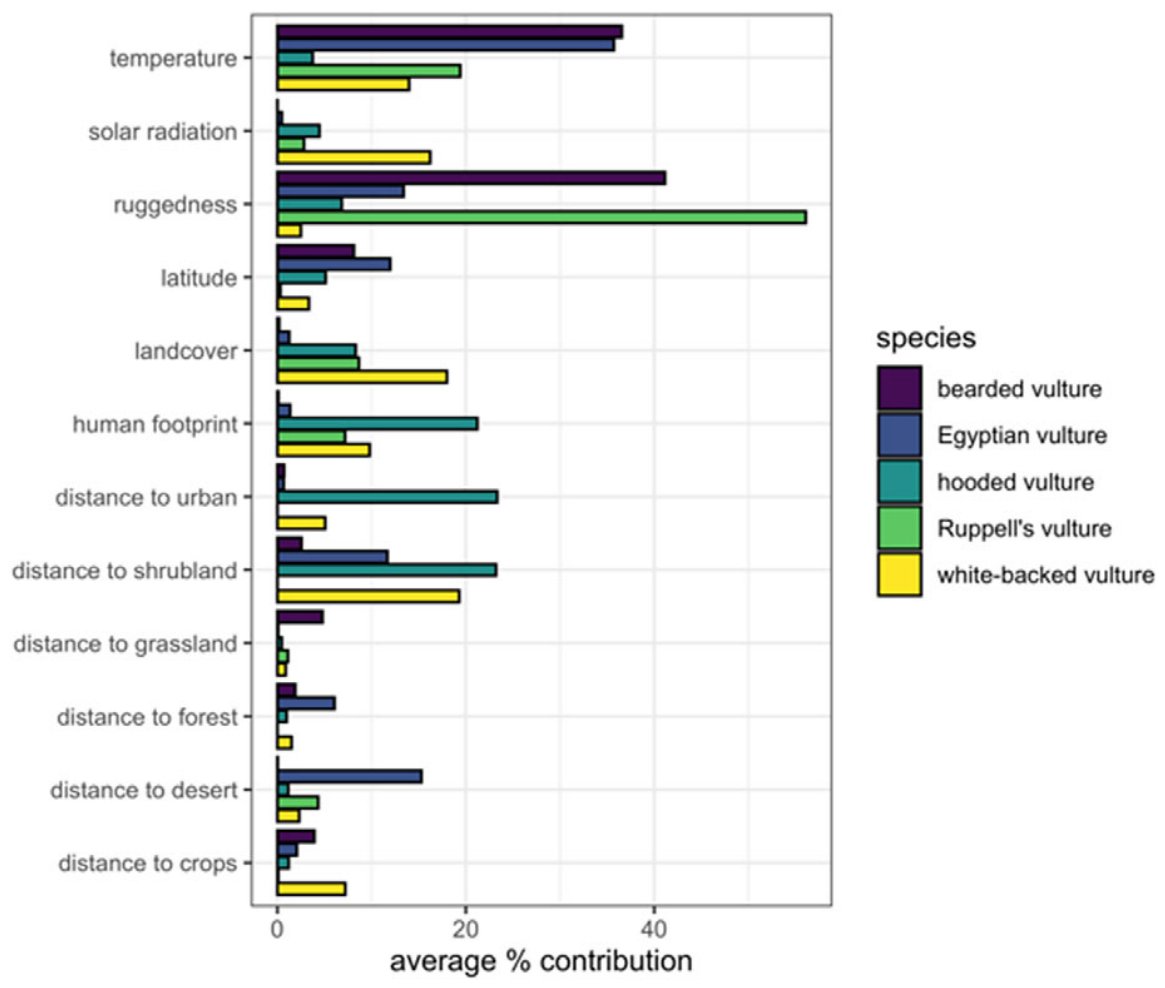

Figure 2. Average percent contribution of each predictor variable to the final ensemble distribution model for each species.

persist primarily within protected areas across the continent (Thiollay 2006, Virani et al. 2011, Pomeroy et al. 2014, Murn et al. 2016), with exceptions for Egyptian and Hooded Vultures (Buechley et al. 2018, Henriques et al. 2018). Our results are strikingly similar to global Old World vulture conservation priority areas, for which one-fifth of the top-priority areas are protected and about one-tenth intersect IBAs (Santangeli et al. 2019a).

The limited protection of vulture priority areas indicates that conservation actions must be effective outside the existing protected area network. As has been argued at the global level (Botha et al. 2017, Santangeli et al. 2019a), measures of broad spatial and legislative scope are likely to be necessary to conserve vultures and their respective ecosystem services. Such measures could include legislation aimed at controlling the availability and use of veterinary drugs and poisons that are drivers of vulture declines across Africa (Ogada 2014). Further, comprehensive environmental impact assessments should occur prior to energy infrastructure developments to evaluate and mitigate threats to vultures and other biodiversity (Santangeli et al. 2019a). It will also be imperative to work closely and collaboratively with stakeholders to identify and address local issues, such as human-wildlife conflict, which could contribute to vulture declines. Given that Ethiopia has a disproportionate role in supporting vulture populations (Botha et al. 2017, Buechley et al. 2019, Santangeli et al. 2019a), yet has among the least economic resources globally (World Bank 2019a), we call for increased international attention to and funding for vulture conservation efforts here.

An important next step to improve vulture conservation in the Horn of Africa will be a more detailed assessment of the spatial distribution of threats (Botha et al. 2017). The use of poisons to 
a) vulture priority areas

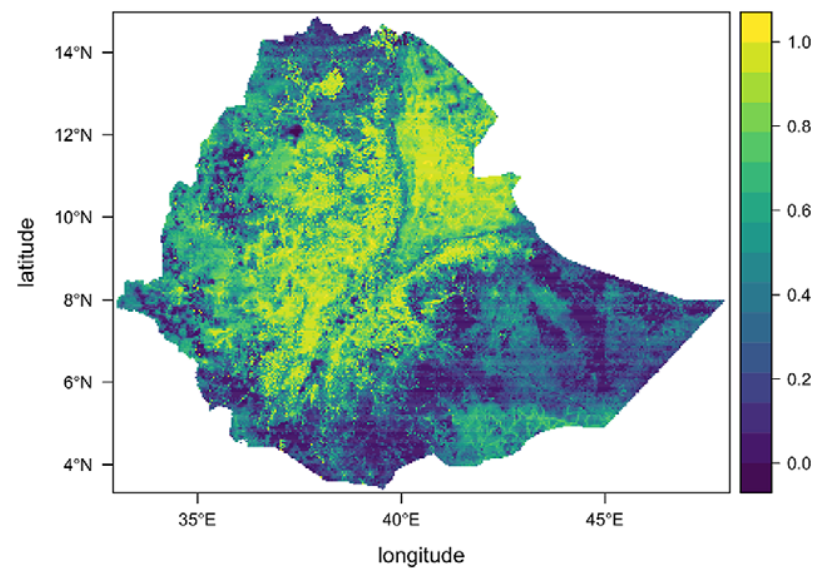

b) priority protected areas

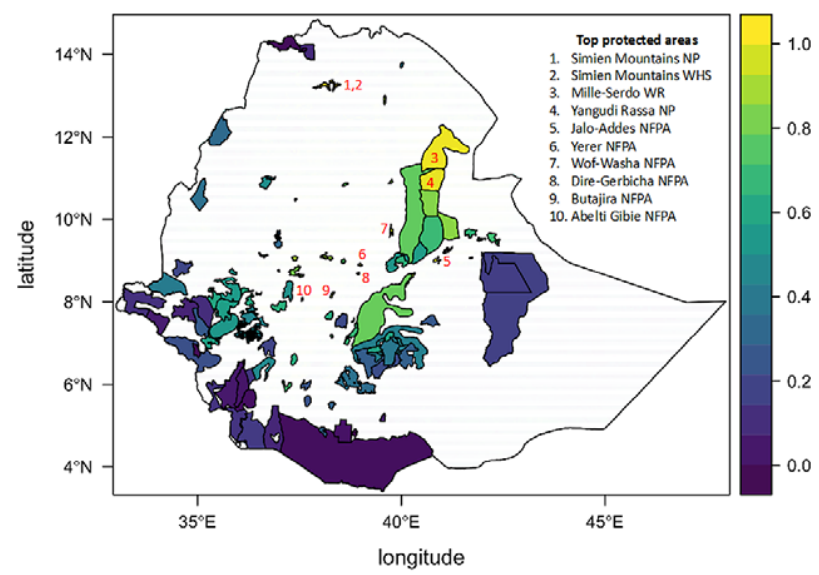

c) priority IBAs

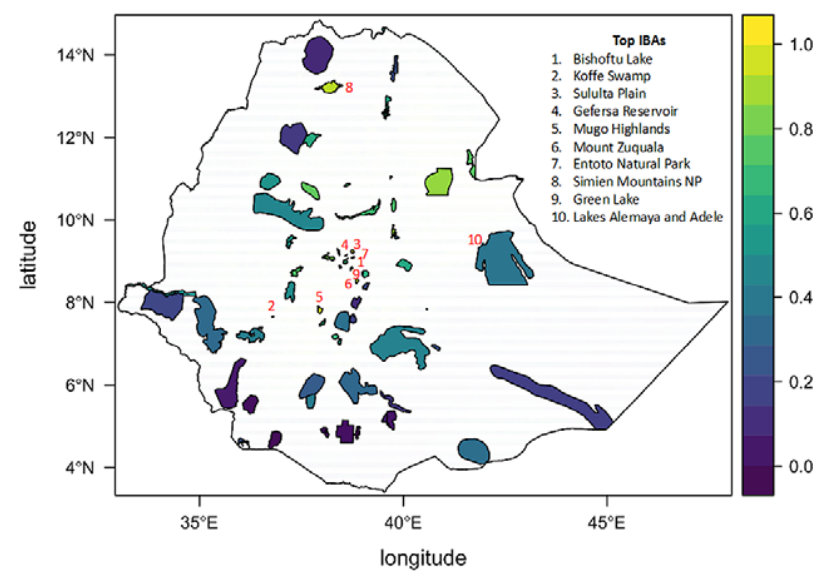

Figure 3. Spatial conservation priorities for vultures in Ethiopia. Panel a) shows the overall spatial priorities, which is the output of the zonation analysis. Panels b) and c) show the rank priority of the protected area (PAs) and Important Bird and Biodiversity Area (IBAs) networks, as well as the topten highest priority site. The colours of the filled polygons correspond with the scale, ranging from o to 1 , which is a relative measure of spatial conservation importance for vultures. 
control feral dog populations by municipalities is apparently widespread and a major danger for vulture populations (Abebe 2013). Further, electrocution on powerlines has been shown to kill Egyptian Vultures in neighboring Sudan (Angelov et al. 2012), and, similarly concerning levels of electrocution of vultures have been recently reported in Ethiopia (Bakari et al. 2020). Ethiopia also has some of the largest wind energy facilities in Africa, with ambitious development targets to grow this sector (Asress et al. 2013). While renewable energy expansion is generally a positive strategy for the development of Ethiopia and global environmental sustainability, poorly situated turbines and high voltage transmission lines can be highly detrimental to soaring birds and other wildlife (Barrios and Rodríguez 2004, Sánchez-Zapata et al. 2016). Climate change is also expected to severely impact the region (Soultan et al. 2019), and, given that temperature was one of the most important predictors for the occurrence of Bearded, Rüppell's, and White-backed Vultures (Figure 2), it could be contributing to range contractions (Simmons and Jenkins 2007, Phipps et al. 2017). Further, we call for a review and update of the IBA network in Ethiopia, which is outdated and largely focused on wetland and riparian areas. The vulture conservation priority areas that were identified herein could be the basis for several additional IBAs, per the AI Global IBA Criterion for globally threatened species (BirdLife International 2020).

The predicted distributions of vultures herein indicate that Egyptian, Hooded, and White-backed Vultures favour human dominated landscapes and proximity to urban areas. The Egyptian Vulture is known to regularly congregate at refuse dumps (Tauler-Ametller et al. 2017, Buechley et al. 2018, McGrady et al. 2019), and Hooded Vultures are known to associate with humans, particularly in West Africa and Ethiopia (Mundy et al. 1993, Mullié et al. 2017, Henriques et al. 2018, Thompson et al. 2020). In contrast, the White-backed Vulture is more widely regarded as averse to human dominated landscapes, or having already declined precipitously in them, to the point that it occurs mainly within protected areas across much of Africa (e.g. Thiollay 2006, Virani et al. 2011, Pomeroy et al. 2014; although note that tracked immatures in southern Africa spent the majority of their time outside of protected areas (Phipps et al. 2013). Provided that we tracked Hooded and Egyptian Vultures that were caught in the vicinity of towns, there could be some sampling bias in our models. However, these results are fully congruent with our extensive observations throughout the country. Vulture coexistence with humans in Ethiopia may be regarded as a mutualistic relationship (Gangoso et al. 2013, Moleón et al. 2014). Vulture ecosystem services, while rarely robustly quantified, are now widely recognized (Şekercioğlu 2006, Buechley and Şekercioğlu 2016a,b, Devault et al. 2016), including efficient nutrient cycling and carrion removal, reduction in greenhouse gas emissions (Morales-Reyes et al. 2015, 2017), controlling problematic facultative scavengers and insects (Ogada et al. 2012b, Buechley and Şekercioğlu 2016a), and potentially limiting the spread of disease (Markandya et al. 2008, Buechley and Şekercioğlu 2016a, Şekercioglu et al. 2016, Plaza et al. 2020). Nonetheless, the association of some species of vultures with humans, and their reliance on human waste may constitute an ecological trap for vultures in the $21^{\text {st }}$ century (Ogada et al. 2012a, Buechley and Şekercioğlu 2016a).

Notably, we found that the Egyptian Vulture distribution was concentrated in north-eastern Ethiopia. Other research has shown the importance of this area for the species, particularly for overwintering migrant populations (Arkumarev et al. 2014, Buechley et al. 2018). However, surveys and observations of the species in Ethiopia in the $20^{\text {th }}$ century (Ash and Atkins 2009) indicated a more widespread distribution, with resident populations throughout the country. Our sample of occurrence records for this species was likely biased towards migrants because 13 of 15 tracked Egyptian Vultures were migrants and road surveys were done when most migrants had already arrived in Ethiopia. Nonetheless, that we had few records across much of Ethiopia indicates potential decline in the resident population in Ethiopia, and merits further investigation.

Unfortunately, we were unable to produce informative models of the distributions of Lappetfaced and White-headed Vultures, due to low sample sizes. Surveys in the last century indicated widespread distributions of both of these species in Ethiopia (Ash and Atkins 2009), and recent work has predicted occurrence of the latter species in Ethiopia (Murn et al. 2016). However, these species were the least reported from citizen science observations and road surveys (Table 1 ). This is 
not unexpected, as these species are more solitary and averse to human activity. We encourage further targeted survey work on these two species to better understand their distributions, status, and priority conservation areas in the Horn of Africa. Additionally, SDMs built on telemetry and citizen science data from White backed Vulture were uninformative (AUC <0.6; Table I). We believe this occurred because the White-backed Vulture is a generalist species that can be found across all habitats and elevations, and in both human-dominated and wild environments in Ethiopia, which made it difficult to identify strong signals of habitat association in our models.

There are several potential limitations to our data sources and analyses. In addition to the paucity of data for certain species, as discussed above, we had sparse data from the Somali Region of southeastern Ethiopia due to security issues inhibiting access. Thus, we caution that the modelled predictions for this region are extrapolatory and should be taken as a first indication of potential areas to target further investigations. Further, we recognize that spatial sampling biases across the three data types could have influenced our models. For example, road surveys were restricted to areas proximate to roads, citizen science data tend to be concentrated in human-populated areas, and tracking data may be influenced by individual behaviour and tagging locations. We worked to address these potential biases, following recommendations in Merow et al. (2013), by limiting the background sample in each species-data type model to areas that were surveyed or realistically accessible to tracked individuals. To assess how robust our predictions are, we also directly quantified niche overlap between different species-data-type model predictions (Table $\mathrm{S}_{1}$ ), quantified uncertainty in our predictions (Figure $\mathrm{S}_{4}$, Figure $\mathrm{S}_{5}$ ), and deducted areas with more uncertainty in our prioritization exercise. Overall results indicated that our models were largely robust to uncertainty. Further, our models lacked some predictor variables that could be important for vulture space use (for example, the location of carcasses). We expect that predictions could thus be further refined if predictive layers existed that more accurately captured important local aspects of vulture ecology (see relevant discussion here: Efrat et al. 2020, Santangeli et al. 2020).

In summary, we provide here the first detailed assessment of vulture distributions and spatial conservation priorities for one of the most important countries for vulture conservation worldwide. The low coverage of vulture priority areas by protected areas, as well as the association between vultures and human-dominated landscapes, indicates a need for actions of wide temporal and spatial scope (Botha et al. 2017, Santangeli et al. 2019a, Perrig et al. 2020). Enactment and enforcement of legislation will likely be essential to reduce the availability and use of veterinary drugs and poisons that threaten wildlife (Margalida et al. 2014, Ogada 2014). Similarly, use of best practices and thorough implementation of environmental impact assessments prior to energy development projects are necessary. Several international conventions and frameworks exist to facilitate development and enforcement of policy relevant to vulture conservation. For example, Ethiopia is a signatory of the Convention on Biological Diversity (CBD), Convention of Migratory Species (CMS), and the Convention on the International Trade of Endangered Species of Wild Fauna and Flora (CITES), which provide guidelines to support the conservation of wildlife, including vultures. Encouragingly, in 2020 Ethiopia also became a signatory of the Raptors MoU, under CMS, which supports specific actions to reduce mortality of raptors and vultures from poisoning and energy infrastructure (Botha et al. 2017). Such actions, if taken while considering the local social context and in a manner that aids sustainable development, would help to conserve threatened vultures and their critical ecological functions, while also benefiting many other species occurring in this biodiversity hotspot region of global importance. Further, we believe that it is imperative to reduce social and economic inequalities, promote peace, and invest in community-led initiatives in order to achieve biodiversity conservation in Ethiopia (Santangeli et al. 2019b), especially provided the recent increase in social unrest and violence in the country.

\section{Supplementary Materials}

To view supplementary material for this article, please visit http://doi.org/10.1017/

So959270921000228. 


\section{Acknowledgements}

We thank the Ethiopia Wildlife Conservation Authority for collaboration and research permits. We thank the Ethiopia Wildlife and Natural History Society and Addis Ababa University Department of Zoology for collaboration and technical support. Thanks to Sisay Seyfu for facilitating all work, and to Andres de la Cruz Muñoz, Juan Ramirez Roman, and Gabriel Caucal for participating in surveys. We thank Steffen Oppel, whose constructive comments helped to improve the manuscript. We are grateful to HawkWatch International, the National Geographic Society, the University of Utah, the Deutsche Forschungsgemeinschaft (DFG, German Research Foundation) under Germany's Excellence Strategy - EXC 2117 - 422037984, the Wallace Research Foundation, The Peregrine Fund, Dutch zoos (notably Avifauna and Blijdorp), and WWF Netherlands for funding. The following HawkWatch International donors sponsored the vulture tracking project: Antczak Polich Law, Buddy Woodhouse, Circle of Life Fund, Doug and Tana Hunter, Eva Carlston Academy, Glen and Anneli Bowen, Jane Tatchell, Julia Shaw, Kirsten Collins, Nancy and John Matro, Scott and Amy Florell, SWCA Environmental Consultants, Team Kaddas, Valerie Walker, and Walter and Karen Loewenstern. AS was supported by a Finnish Academy fellowship (1307909).

\section{References}

Abebe, Y. D. (2013) Mass dog poisoning operation in Addis Ababa can have severe repercussions on vulture populations. Vulture News 64: 74-76.

Alroy, J. (2017) Effects of habitat disturbance on tropical forest biodiversity. Proc. Natl. Acad. Sci. USA. 114: 6056-6061.

Angelov, I., Hashim, I. and Oppel, S. (2012) Persistent electrocution mortality of Egyptian Vultures Neophron percnopterus over 28 years in East Africa. Bird Conserv. Internatn. 23: 1-6.

Arkumarev, V., Dobrev, V. and Abebe, Y. (2014) Congregations of wintering Egyptian Vultures Neophron percnopterus in Afar, Ethiopia: present status and implications for conservation. Ostrich 85: 139-145.

Aryal, A., Shrestha, U. B., Ji, W., Ale, S. B., Shrestha, S., Ingty, T., Maraseni, T., Cockfield, G. and Raubenheimer, D. (2016) Predicting the distributions of predator (snow leopard) and prey (blue sheep) under climate change in the Himalaya. Ecol. Evol. 6: 4065-4075.

Ash, J. and Atkins, J. (2009) Birds of Ethiopia and Eritrea: an atlas of distribution. London, UK: Christopher Helm.

Asress, M. B., Simonovic, A., Komarov, D. and Stupar, S. (2013) Wind energy resource development in Ethiopia as an alternative energy future beyond the dominant hydropower. Renew. Sustain. Energy Rev. 23: 366-378.

Bakari, S., Mengistu, S., Tesfaye, M., Ruffo, A. D., Oppel, S., Arkumarev, V. and Nikolov, S. C. (2020) Technical report under action $\mathrm{A}_{3}$ of the "Egyptian Vulture New LIFE project": Bird mortality due to hazardous powerlines in East Oromia and Afar regions, Ethiopia, 2019. Nairobi, Kenya: BirdLife Africa.

Barnosky, A. D., Matzke, N., Tomiya, S., Wogan, G. O. U., Swartz, B., Quental, T. B., Marshall, C., McGuire, J. L., Lindsey, E. L., Maguire, K. C., Mersey, B. and Ferrer, E. A. (2011). Has the Earth's sixth mass extinction already arrived? Nature 471: 51-57.

Barrios, L. and Rodríguez, A. (2004) Behavioural and environmental correlates of soaring-bird mortality at on-shore wind turbines. J. Appl. Ecol. 41: 72-81.

Benson, J. F. (2013) Improving rigour and efficiency of use-availability habitat selection analyses with systematic estimation of availability. Methods Ecol. Evol. 4: 244-251.

BirdLife International (2020) BirdLife Data Zone: Global IBA criteria (consulted September 2020: http://datazone.birdlife. org/site/ibacritglob).

Botha, A. J., Andevski, J., Bowden, C. G., Gudka, M., Safford, R. J., Tavares, J. and Williams, N. P. (2017) Multi-species action 
plan to conserve African-Eurasian vultures (vulture MsAP). Abu Dhabi, United Arab Emirates: Coordinating Unit of the CMS Raptors MOU. (CMS Raptors MOU Technical Publication No. 5. CMS Technical Series No. 35).

Brooks, T. M., Mittermeier, R. A., Fonseca, G. A. B. da, Gerlach, J., Hoffman, M., Lamoreux, J. F., Mittermeier, C. G., Pilgrim, J. D. and Rodrigues, A. S. L. (2006) Global biodiversity conservation priorities. Science 313: 58-62.

Buechley, E. R., McGrady, M. J., Çoban, E. and Şekercioğlu, Ç. H. (2018) Satellite tracking of a wide ranging endangered vulture species to target conservation actions in the Middle East and Horn of Africa. Biodivers. Conserv. 27: 2293-2310.

Buechley, E. R., Santangeli, A., Girardello, M., Neate-Clegg, M. H., Oleyar, D. McClure, C. J. W. and Şekercioğlu, Ç. H. (2019) Global raptor research and conservation priorities: tropical raptors fall prey to knowledge gaps. Divers. Distrib. 25: 856-869.

Buechley, E. R. and Şekercioğlu, Ç. H. (2016a) The avian scavenger crisis: looming extinctions, trophic cascades, and loss of critical ecosystem functions. Biol. Conserv. 198: 220-228.

Buechley, E. R. and Şekercioğlu, Ç. H. (2016b) Vultures. Curr. Biol. 26: R56o-R561.

Burnham, K. P. and Anderson, D. R. (2004) Multimodel inference: Understanding AIC and BIC in model selection. Sociol. Methods Res. 33: 261-304.

Cadotte, M. W., Carscadden, K. and Mirotchnick, N. (2011) Beyond species: Functional diversity and the maintenance of ecological processes and services. J. Appl. Ecol. 48: 1079-1087.

Calenge, C. (2011) Home range estimation in R: the adehabitatHR Package. I-28. http:// cran.r-project.org/web/packages/ade habitatHR/

Coxen, C. L., Frey, J. K., Carleton, S. A. and Collins, D. P. (2017) Species distribution models for a migratory bird based on citizen science and satellite tracking data. Glob. Ecol. Conserv. 11: 298-311.

Devault, T. L., Beasley, J. C., Olson, Z. H., Moleón, M., Carrete, M., Margalida, A. and Sánchez-zapata, J. A. (2016) Ecosystem services provided by avian scavengers. Pp. 235-270 in C. H. Sekercioglu, D. G. Wenny, and C. J. Whelan, eds. Why birds matter: Avian ecological function and ecosystem services. Chicago, USA: The University of Chicago Press.

Efrat, R., Hatzofe, O. and Berger-tal, O. (2020) Translating large-scale prioritization models for vultures to local-scale decision making. Conserv. Biol. 5: 1305-1307.

Elith, J., Phillips, S. J., Hastie, T., Dudík, M., Chee, Y. E. and Yates, C. J. (2011) A statistical explanation of MaxEnt for ecologists. Divers. Distrib. 17: 43-57.

European Space Agency (2017) African land cover. https://www.esa.int/ESA_Multime dia/Images/2017/Io/African_land_cover

Evans, L. J., Asner, G. P. and Goossens, B. (2018) Protected area management priorities crucial for the future of Bornean elephants. Biol. Conserv. 221: 365-373.

Ferraz, K., De Barros, M. P. M., De Siqueira, M. F., Alexandrino, E. R., Da Luz, D. T. A. and Do Couto, H. T. Z. (2012) Environmental suitability of a highly fragmented and heterogeneous landscape for forest bird species in south-eastern Brazil. Environ. Conserv. 39: 316-324.

Fick, S. E. and Hijmans, R. J. (2017) Worldclim 2: New 1-km spatial resolution climate surfaces for global land areas. Int. J. Climatol. 37: 4302-5315.

Fletcher, R. J. Jr., Hefley, T. J., Robertson, E. P., Zuckerberg, B., McCleery, R. A. and Dorazio, R. M. (2018) A practical guide for combining data to predict species distributions. Ecology 100: e02710.

Gangoso, L., Agudo, R., Anadon, J. D., De la Riva, M., Suleyman, A. S., Porter, R. and Donazar, J. A. (2013) Reinventing mutualism between humans and wild fauna: insights from vultures as ecosystem services providers. Conserv. Lett. 6: 172-179.

Ghosh-Harihar, M., An, R., Athreya, R., Borthakur, U., Chanchani, P., Chetry, D., Datta, A., Harihar, A., Karanth, K. K., Mariyam, D., Mohan, D., Onial, M., Ramakrishnan, U., Robin, V. V., Saxena, A., Shahabuddin, G., Thatte, P., Vijay, V., Wacker, K., Mathur, V. B., Pimm, S. L. and 
Price, T. D. (2019) Protected areas and biodiversity conservation in India. Biol. Conserv. 237: 114-124.

Guisan, A. and Thuiller, W. (2005) Predicting species distribution: Offering more than simple habitat models. Ecol. Lett. 8: 993-1009.

Henriques, M., Granadeiro, J. P., Monteiro, H., Nuno, A., Lecoq, M., Cardoso, P., Regalla, A. and Catry, P. (2018) Not in wilderness: African vulture strongholds remain in areas with high human density. PLoS One 13: eo190594.

Horns, J. J., Adler, F. R. and Şekercioğlu, Ç. H. (2018) Using opportunistic citizen science data to estimate avian population trends. Biol. Conserv. 221: 151-159.

IUCN and UNEP-WCMC (2018) The World Database on Protected Areas (WDPA). Gland, Switzerland: IUCN.

Johnston, A., Hochachka, W. M., StrimasMackey, M., Gutierrez, V. R., Robinson, O. J., Miller, E. T., Auer, T., Kelling, S. T. and Fink, D. (2019) Best practices for making reliable inferences from citizen science data: case study using eBird to estimate species distributions. bioRxiv 574392.

Joppa, L. N., O'Connor, B., Visconti, P., Smith, C., Geldmann, J., Hoffmann, M., Watson, J. E. M., Butchart, S. H. M., Virah-Sawmy, M., Halpern, B. S., Ahmed, S. E., Balmford, A., Sutherland, W. J., Harfoot, M., HiltonTaylor, C., Foden, W., Minin, E. Di, Pagad, S., Genovesi, P., Hutton, J. and Burgess, N. D. (2016. Filling in biodiversity threat gaps. Science 352: 416-418.

Kendall, C. J., Virani, M. Z., Hopcraft, J. G. C., Bildstein, K. L. and Rubenstein, D. I. (2014) African vultures don't follow migratory herds: scavenger habitat use is not mediated by prey abundance. PLoS One 9: 1-8.

Margalida, A., Bogliani, G., Bowden, C. G. R., Donazar, J. A., Genero, F., Gilbert, M., Karesh, W. B., Kock, R., Lubroth, J., Manteca, X., Naidoo, V., Neimanis, A., Sanchez-Zapata, J. A., Taggart, M. A., Vaarten, J., Yon, L., Kuiken, T. and Green, R. E. (2014) Science and regulation. One Health approach to use of veterinary pharmaceuticals. Science 346: 1296-1298.

Markandya, A., Taylor, T., Longo, A., Murty, M. N., Murty, S. and Dhavala, K. (2008)
Counting the cost of vulture decline-an appraisal of the human health and other benefits of vultures in India. Ecol. Econ. 67: 194-204.

McGrady, M. J., Karelus, D. L., Rayaleh, H. A., Sarrouf Willson, M., Meyburg, B.-U., Oli, M. K. and Bildstein, K. (2019) Home ranges and movements of Egyptian Vultures Neophron percnopterus in relation to rubbish dumps in Oman and the Horn of Africa. Bird Study https://doi.org/10.1080/ 00063657.2018 .1561648$.

Merow, C., Smith, M. J. and Silander, J. A. (2013) A practical guide to MaxEnt for modeling species' distributions: What it does, and why inputs and settings matter. Ecography (Cop.). 36: 1058-1069.

Miller, D. A. W., Pacifici, K., Sanderlin, J. S. and Reich, B. J. (2019) The recent past and promising future for data integration methods to estimate species' distributions. Methods Ecol. Evol. 10: 22-37.

Moilanen, A., Pouzols, F. M., Meller, L., Veach, V., Arponen, A., Leppänen, J. and Kujala, H. (2014) Zonation- Spatial Conservation Planning Methods and Software Version 4 User Manual. https://researchportal.hel sinki.fi/en/publications/zonation-spatialconservation-planning-framework-andsoftware-ver

Moilanen, A., Wintle, B. A., Elith, J. and Burgman, M. (2006) Uncertainty analysis for regional-scale reserve selection. Conserv. Biol. 20: 1688-1697.

Moleón, M., Sánchez-Zapata, J. a., Margalida, A., Carrete, M., Owen-Smith, N. and Donázar, J. A. (2014) Humans and scavengers: The evolution of interactions and ecosystem services. Bioscience 64: 394-403.

Morales-Reyes, Z., Pérez-García, J. M., Moleón, M., Botella, F., Carrete, M., Donázar, J. A., Cortés-Avizanda, A., Arrondo, E., Moreno-Opo, R., Jiménez, J., Margalida, A. and Sánchez-Zapata, J. A. (2017) Evaluation of the network of protection areas for the feeding of scavengers in Spain: from biodiversity conservation to greenhouse gas emission savings. J. Appl. Ecol. 54: 1120-1129.

Morales-Reyes, Z., Pérez-García, J. M., Moleón, M., Botella, F., Carrete, M., Lazcano, C., Moreno-Opo, R., Margalida, 
A., Donázar, J. A. and Sánchez-Zapata, J. A. (2015) Supplanting ecosystem services provided by scavengers raises greenhouse gas emissions. Sci. Rep. 5:.

Mukherjee, A., Galligan, T. H., Prakash, V., Paudel, K., Khan, U., Prakash, S., Ranade, S., Shastri, K., Dave, R., Donald, P. and Bowden, C. (2014) Vulture Safe Zones to save Gyps Vultures in South Asia. Mistnet 53: 1-38.

Mullié, W. C., Couzi, F., Diop, M. S., Piot, B., Peters, T. and Reynaud, P. A. (2017) The decline of an urban Hooded Vulture Necrosyrtes monachus population in Dakar, Senegal, over 50 years. Ostrich 88: 131-138.

Mundy, P. P., Bunchart, D., Ledger, J. and Piper, S. (1993) The vultures of Africa. London, UK: Academic Press.

Murn, C., Mundy, P., Virani, M. Z., Borello, W. D., Holloway, G. J. and Thiollay, J.-M. (2016) Using Africa's protected area network to estimate the global population of a threatened and declining species: a case study of the Critically Endangered Whiteheaded Vulture Trigonoceps occipitalis. Ecol. Evol. 6: 1092-1103.

Muscarella, R., Galante, P. J., Soley-Guardia, M., Boria, R. A., Kass, J. M., Uriarte, M. and Anderson, R. P. (2014) ENMeval: An R package for conducting spatially independent evaluations and estimating optimal model complexity for Maxent ecological niche models. Methods Ecol. Evol. 5: 1198-1205.

Neate-Clegg, M.H.C., Horns, J.J., Adler, F.R., Kemahlı Aytekin, M.Ç., Şekercioğlu, Ç.H. 2020. Monitoring the world's bird populations with community science data. Biological Conservation 248: 108653.

Ogada, D. L. (2014) The power of poison: pesticide poisoning of Africa's wildlife. Ann. N.Y. Acad. Sci. 1322: 1-20.

Ogada, D. L., Keesing, F. and Virani, M. (2012a) Dropping dead: causes and consequences of vulture population declines worldwide. Ann. N.Y. Acad. Sci. 1249: 57-71.

Ogada, D., Torchin, M., Kinnaird, M. and Ezenwa, V. (2012b) Effects of vulture declines on facultative scavengers and potential implications for mammalian disease transmission. Conserv. Biol. 26: 453-46o.
Perrig, P. L., Lambertucci, S. A., Cruz, J., Alarcón, P. A. E., Plaza, P. I., Middleton, A. D., Blanco, G., Sánchez-Zapata, J. A., Donázar, J. A. and Pauli, J. N. (2020) Identifying conservation priority areas for the Andean condor in southern South America. Biol. Conserv. 243: 108494.

Phillips, S. J., Anderson, R. P. and Schapire, R. E. (2006) Maximum entropy modeling of species geographic distributions. 190: 231-259.

Phipps, W. L., Diekmann, M., MacTavish, L. M., Mendelsohn, J. M., Naidoo, V., Wolter, K. and Yarnell, R. W. (2017) Due south: A first assessment of the potential impacts of climate change on Cape vulture occurrence. Biol. Conserv. 210: 16-25.

Phipps, W. L., Willis, S. G., Wolter, K. and Naidoo, V. (2013) Foraging ranges of immature African White-Backed Vultures (Gyps africanus) and their use of protected areas in Southern Africa. PLoS One 8: e52813.

Plaza, P. I., Blanco, G. and Lambertucci, S. A. (2020) Implications of bacterial, viral and mycotic microorganisms in vultures for wildlife conservation, ecosystem services and public health. Ibis 162: 1109-1124.

Plaza, P. I., Martínez-López, E. and Lambertucci, S. A. (2019) The perfect threat: Pesticides and vultures. Sci. Total Environ. 687: 1207-1218.

Pomeroy, D., Shaw, P., Opige, M., Kaphu, G., Ogada, D. L. and Virani, M. Z. (2014) Vulture populations in Uganda: using road survey data to measure both densities and encounter rates within protected and unprotected areas. Bird Conserv. Internatn. 25: 399-414.

R Core Team (2019) R: A language and environment for statistical computing. Vienna, Austria: R Foundation for Sytistical Computing.

Randin, C. F., Dirnböck, T., Dullinger, S., Zimmermann, N. E., Zappa, M. and Guisan, A. (2006) Are niche-based species distribution models transferable in space? J. Biogeogr. 33: 1689-1703.

Robinson, N., Regetz, J. and Guralnick, R. P. (2014) EarthEnv-DEM9o: A nearly-global, void-free, multi-scale smoothed, 9om digital elevation model from fused ASTER and SRTM data. ISPRS J. Photogramm. Remote Sens. 87: 57-67. 
Runge, C. A., Martin, T. G., Possingham, H. P., Willis, S. G. and Fuller, R. A. (2014) Conserving mobile species. Front. Ecol. Environ. 12: 395-402.

Runge, C. A., Watson, J. E. M., Butchart, S. H. M., Hanson, J. O., Possingham, H. P. and Fuller, R. A. (2015) Protected areas and global conservation of migratory birds. Science 350: 1255-1258.

Sánchez-Zapata, J. A., Clavero, M., Carrete, M., DeVault, T. L., Hermoso, V., Losada, M. A., Polo, M. J., Sánchez-Navarro, S., Pérez-García, J. M., Botella, F., Ibáñez, C. and Donázar, J. A. (2016) Effects of renewable energy production and infrastructure on wildlife. Wildl. Res. Monogr. Springer International Publishing, Switzerland, pp. 97-123.

Santangeli, A., M. Girardello, E. Buechley, A. Botha, E. Di Minin, and A. Moilanen (2019). Priority areas for conservation of Old World vultures. Conservation Biology 33:10561065.

Santangeli, A., Girardello, M., Buechley, E., Botha, A., Minin, E. Di and Moilanen, A. (2019a) Priority areas for conservation of Old World vultures. Conserv. Biol. 5: 1056-1065.

Santangeli, A., Girardello, M., Buechley, E., Botha, A., Minin, E. Di and Moilanen, A. (2020) Importance of complementary approaches for efficient vulture conservation: reply to Efrat et al. Conserv. Biol. IO.IIII/cobi.I3579.

Santangeli, A., Girardello, M., Buechley, E. R., Eklund, J. and Phipps, W. L. (2019b) Navigating spaces for implementing raptor research and conservation under varying levels of violence and governance in the Global South. Biol. Conserv. 239: 108212.

Şekercioğlu, Ç. H. (2006) Ecological significance of bird populations. Handbook of the birds of the world. 11: 15-51. Barcelona, Spain: Lynx Edicions.

Şekercioğlu, Ç. H. (2010) Ecosystem functions and services. Pp.45-72 in N. S. Sodhi and P. Ehrlich, eds. Conservation biology for all. Oxford, UK: Oxford University Press.

Şekercioğlu, Ç. H., Whenny, D. and Whelan, C. J. (2016) Why birds matter: avian ecological function and ecosystem services,
Ç. H. Şekercioğlu D. Whenny and C. J. Whelan (eds.), Chicago, USA: University of Chicago Press.

Simmons, R. E. and Jenkins, A. R. (2007) Is climate change influencing the decline of Cape and Bearded Vulures in southern Africa? Vulture News 56: 41-51.

Soultan, A., Wikelski, M. and Safi, K. (2019) Risk of biodiversity collapse under climate change in the Afro-Arabian region. Sci. Rep. 9: $1-12$.

Phillips, S. J. and Dudík, R. E. S. (2020) Maxent software for modeling species niches and distributions (consulted March 202O: http://biodiversityinformatics.amnh.org/ open_source/maxent/).

Sullivan, B. L., Aycrigg, J. L., Barry, J. H., Bonney, R. E., Bruns, N., Cooper, C. B., Damoulas, T., Dhondt, A. A., Dietterich, T., Farnsworth, A., Fink, D., Fitzpatrick, J. W., Fredericks, T., Gerbracht, J., Gomes, C., Hochachka, W. M., Iliff, M. J., Lagoze, C., La Sorte, F. A., Merrifield, M., Morris, W., Phillips, T. B., Reynolds, M., Rodewald, A. D., Rosenberg, K. V., Trautmann, N. M., Wiggins, A., Winkler, D. W., Wong, W. K., Wood, C. L., Yu, J. and Kelling, S. (2014) The eBird enterprise: An integrated approach to development and application of citizen science. Biol. Conserv. 169: 31-40.

Tauler-Ametller, H., Hernández-Matías, A., Pretus, J. L. and Real, J. (2017) Landfills determine the distribution of an expanding breeding population of the endangered Egyptian Vulture Neophron percnopterus. Ibis 159: 757-768.

Taylor, A. T., Hafen, T., Holley, C. T., González, A. and Long, J. M. (2020) Spatial sampling bias and model complexity in stream-based species distribution models: A case study of Paddlefish (Polyodon spathula) in the Arkansas River basin, USA. Ecol. Evol. 10: 705-717.

Thiollay, J.-M. (2006) The decline of raptors in West Africa: long-term assesment and the role of protected areas. Ibis 148: 240-254.

Thompson, L. J., Barber, D., Bechard, M., Botha, A. J., Wolter, K., Neser, W., Buechley, E. R., Reading, R., Garbett, R., Hancock, P., Maude, G., Virani, M. Z., Thomsett, S., Lee, H., Ogada, D., Barlow, C. R. and Bildstein, K. L. (202O) Variation in monthly sizes of 
home-ranges of Hooded Vultures Necrosyrtes monachus in western, eastern, and southern Africa. Ibis 162: 1324-1338.

Trimble, M. J. and van Aarde, R. J. (2012) Geographical and taxonomic biases in research on biodiversity in humanmodified landscapes. Ecosphere 3: arti19.

Venter, O., Sanderson, E. W., Magrach, A., Allan, J. R., Beher, J., Jones, K. R., Possingham, H. P., Laurance, W. F., Wood, P., Fekete, B. M., Levy, M. A. and Watson, J. E. M. (2016) Global terrestrial human footprint maps for 1993 and 2009. Sci. Data 3: 1-10.

Virani, M., Kendall, C., Njoroge, P. and Thomsett, S. (2011) Major declines in the abundance of vultures and other scavenging raptors in and around the Masai Mara ecosystem, Kenya. Biol. Conserv. 144: 746-752.

Warren, D. L., Glor, R. E. and Turelli, M. (2008) Environmental niche equivalency versus conservatism: Quantitative approaches to niche evolution. Evolution 62: 2868-2883.

Wei, T., and V. Simko (2013). corrplot: visualization of a correlation matriz. $\mathrm{R}$ package. $<$ cran.us.r-project.org/web/packages/cor rplot/corrplot.pdf $>$.

World Bank (2019a) GDP per capita (consulted February 2019: https://data. worldbank.org/indicator/ny.gdp.pcap.cd? year_high_desc=false).

World Bank (2019b). Population growth (annual \%). https://data.worldbank.org/ indicator/SP.POP.GROW?view=chart). (consulted February 2019). 